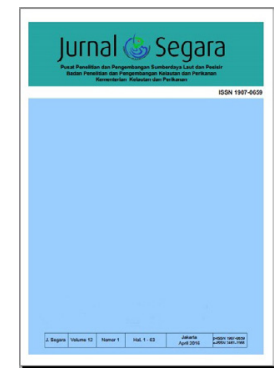

JURNAL SEGARA

http://ejournal-balitbang.kkp.go.id/index.php/segara

ISSN : 1907-0659

e-ISSN : 2461-1166

Nomor Akreditasi: 766/AU3/P2MI-LIPI/10/2016

\title{
THE IMPACT OF ENVIRONMENTAL CHANGING, FOOD AVAILABILITY AND ANTROPOGENIC PRESSURE ON SARDINE (SARDINELLA LEMURU) CPUE IN BALI STRAIT WATERS
}

\author{
THE IMPACT OF ENVIRONMENTAL CHANGING, \\ FOOD AVAILABILITY AND ANTROPOGENIC PRESSURE \\ ON SARDINE (SARDINELLA LEMURU) CPUE IN BALI STRAIT WATERS
}

\author{
Reny Puspasari'1), Puput F. Rahmawati'1), Eko Susilo², Wijopriono1) \& Ngurah N. Wiadnyana1) \\ ${ }^{1)}$ Research Centre for Fisheries \\ ${ }^{2}$ Institute of Marine research and Observation
}

Received: 05 August 2018; Revised: 25 August 2018; Accepted: 31 August 2018

\begin{abstract}
ABSTRAK
As a dominant small pelagic fishery in Bali Strait waters, significant decrease of sardine (lemuru) production was bothering fisheries industries, particularly in Muncar and Pengambengan District in East Java and Bali province. Besides of over exploitation, changing environment condition such as temperature, salinity and thermocline depth, indicated the affect on decreasing of sardine production. The interaction among environment variabels, food source availability (Chl-a) and anthropogenic pressure (fishing effort) generate the number of sardine abundance showed by CPUE (Catch per Unit Effort) value that determined sardine production. The current research aims to analyze the simultant impact of changing environment, food availability and antropogenic pressure on sardine CPUE. Field research was conducted in Bali Strait where primary and secondary fisheries data were gathered at Muncar Fishing Port of Banyuwangi District East Java Province and Pengambengan Fishing Port of Jembrana District Bali Province. Oceanography data such as temperature, salinity, and chlorophyll-a profile were collected from INDESO Model. Data analysis was done by time series analysis of each variabels such as CPUE, SST and SSTA, thermocline depth, chl-a and also the number of trip. Partially analysis of those variabels was done by overlayed one another, and principal component analysis determined to analyze the effect of all those varibales simultaneously on sardine CPUE. Results show that there were an influenced of regional climate phenomenon on the dynamic of environment condition of Bali Strait waters, particularly IOD (Indian Ocean Dipole). The CPUE of sardine was determined by the interaction of environment variabels (SST/SSTA, salinity, thermocline depth), food source availabity (Chl-a) and antropogenic pressure (fishing trip) simultaneously, however SSTA gives a significant negative correlation on CPUE. Regional climate phenomenon might cause an extreme condition in Bali Strait waters leading to unstable environment for sardine habitat. Drastically changing habitat condition occured under influenced of extreme condition would lead to disruption of sardine CPUE.
\end{abstract}

Keywords: Bali sardines (lemuru), environmental changing, chlorophyll-a, fishing pressure.

Corresponding author:

Jl. Pasir Putih I Ancol Timur, Jakarta Utara 14430. Email: reny.paksi@gmail.com 


\section{INTRODUCTION}

Small pelagic fisheries are the important fisheries in Bali Strait with a production in 2015 of about 31,019 ton. $\mathrm{yr}^{-1}$. Then the production had been decreased since 2008, with significantly decreasing of production in 2010 (33\% lower than 2009). In 2011 - 2013, production of small pelagic fishes in Bali strait continued to decreaseand reached the lowest number of production in 2013.

Sardine fish (Sardinella lemuru) are caught in Bali Strait by mini purse seine, danish seine, lift net and gill net, operated in Bali Strait. The production of sardine has contributed $68 \%$ dominated small pelagic landed at Muncar Fishing Port and $93 \%$ of total small pelagic landed at Pengambengan Fishing Port. In normal condition, sardine is dominated the small pelagic catch landing in those two fishing port all the years. In some extreme periods, sardine decreased in production and other small pelagic fishes group increased, such as scads and neritic tunas. As food source, sardine is an important fishery commodity due to its high content of omega 3 (Mahrus et al., 2012), and become a raw material in the fish canning industry.

Sardines have been exploited since 1980s by using purse seine that significantly increased it fishing capacity (Merta, 1992). In the last decade, sardine has been over exploited which is indicated by the value of spawning ratio biomass less than $20 \%$, and the average length of fish catch (SL50) less than the average length of the first maturity (Lm) (Wujdi \& Wudianto, 2015). Fishing creates a significant anthropogenic pressure on sardine production.

According to Purwanto (2011) and Prasetyo \&
Natsir (2010), production of sardine fish in Bali Strait might be influenced by climate phenomenon such as southern oscillation. However the climate phenomenon is not directly influencing the sardine production, there should be an oceanographic mechanism that may change the habitat condition of sardine. On the other hand, the dynamic of sardine production is a simultaneous impact of any variables, such as environment, food availability and fishing effort. The environment changes will influence the habitat condition of sardine, affecting the suitability of the habitat for sardine to stay around. The environment conditions determined the fish habitat most are temperature, salinity, chlorophyll-a (the availability of food source) and thermocline depth that will be influencing the swimming area. More specific both temperature and clorophyl-a or partially just colorophly-a may affect the value of CPUE of pelagic fish (Suniada \& Susilo, 2017). However, the need of more comprehensive analysis is crucial to know the impact of oceanographical condition to variation of sardine production in Bali Strait. Such information is important as knowledge to anticipate the fluctuative sardine production in order to manage the stock of sardine in Bali Strait. The current research aims to evaluate the influence of environment variabels to CPUE of sardine, with considering the fishing effort and food availability. In this work some environmental variables that influence CPUE of sardine will be determined, and how those variables are related to one another and fishing effort.

\section{METHODOLOGY}

Field research was conducted in Bali Strait waters during 2015 to 2016 . Fisheries data were gathered in two landing sites at Pengambengan Fishing Port in Bali

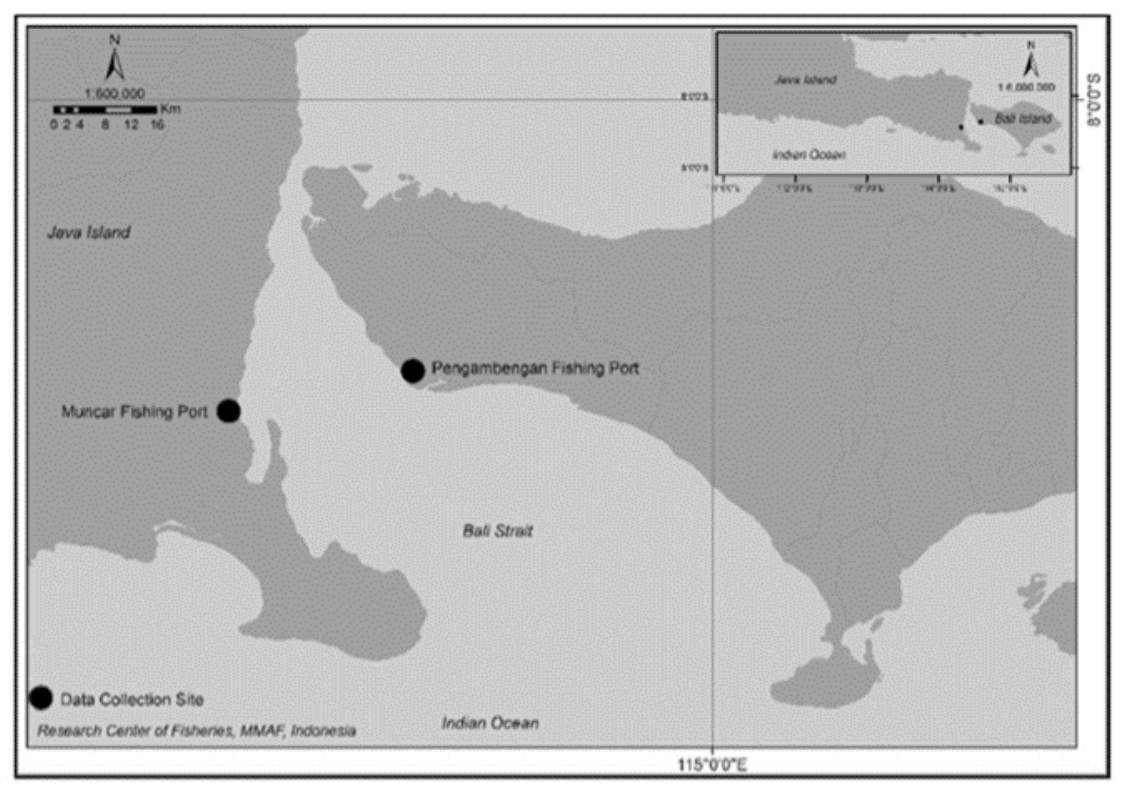

Figure 1. Map showing the field research area. 
Province and Muncar Fishing Port in East Java Province (Figure 1).

Data collected are daily fish catch and trip number. Fish abundance is determined by the value of catch per unit effort (CPUE) that was calculated by dividing the monthly catch yields (in $\mathrm{kg}$ ) with trip number (trip).

To describe the oceanography condition of Bali Strait, model data including sea water temperature from 0 - 100 meters depth, salinity, thermocline depth, and chlorophyll-a concentration, were downloaded from INDESO (www.indeso.web.id). The model data were used to get a continuous monthly time series data of Bali Strait.

Dipole mode index (DMI) data used to show the magnitude of IOD, were downloaded from http://www. jamstec.go.jp. The else, the Southern Oscillation Index (SOI) data used as an index of ENSO were downloaded from https://www.ncdc.noaa.gov. All data (oceanography, DMI, and SOI) were then analyzed by using deseasonality technique such as center moving average. This technique is important to get the better smooth data due to the variability of clear seasonality of the data.

Time delayed analysis was applied to determine a significance response of changing climate index to oceanography condition and fisheries, according to some previous researches (Lumbangaol et al., 2004) who stated that there is a time lag between environment changing and sardine production. Response of sardine fish catch rate to environment and anthropogenic stress was analyzed by principal component analysis.

\section{RESULTS AND DISCUSSION}

\section{The Pattern of Bali sardine production}

The seasonal model of Bali sardine production shows maximum sardine production occured in coincide with the rainy season from around October - February and the minimum sardine production in around July - September (Figure 2).

Figure 3 shows that Bali sardine production has been collapsed since 2007 . However, the production is experienced a small increasing one year after, before dramatically disappeared in 2010 - 2011. Since that extreme period, the increasing production of Bali sardine has never been to be likely the previous production (Figure 3).

Figure 4 shows the differences in catch composition by mini purse seine in extreme periods. In the beginning of 2006, the proportion of sardine in production was low, while the proportion of scads and neritic tunas is increased. The proportion of sardine is increased in the end of the year of 2006 then continued in 2007. There was a strong La Nina coupled with normal IOD followed by weak-moderate El Nino coupled with moderate positive IOD, resulting in negative anomaly in SST (more than $-1^{\circ} \mathrm{C}$ ) in 2006. Cooler water temperature at this time did not generate the decreased production due to its association with high upwelling intensity (Amri et al., 2013). These authors showed that the strong positive IOD and El Nino at the end of 2006 is associated with high upwelling intensity initiated high primary productivity, which serves high foods for sardine. The conditions resulted high production of sardine in 2007, a year after a high upwelling intensity occurred.

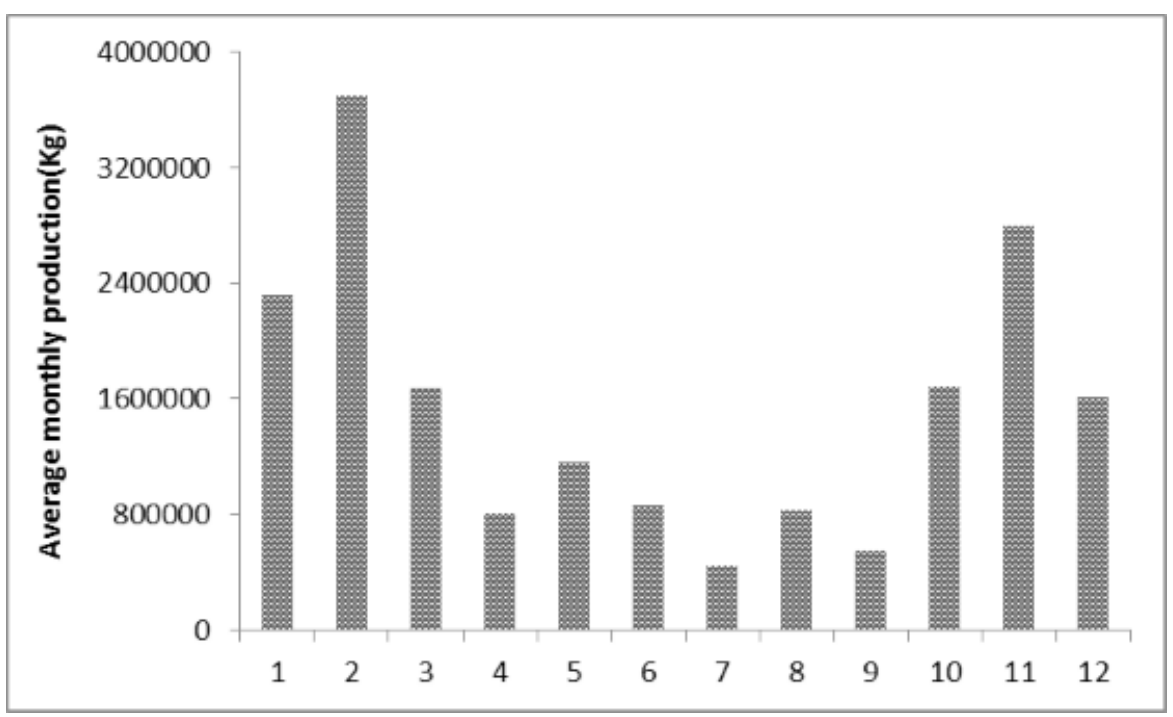

Figure 2. Average of monthly production of sardine (Sardinella lemuru) in Bali strait. 


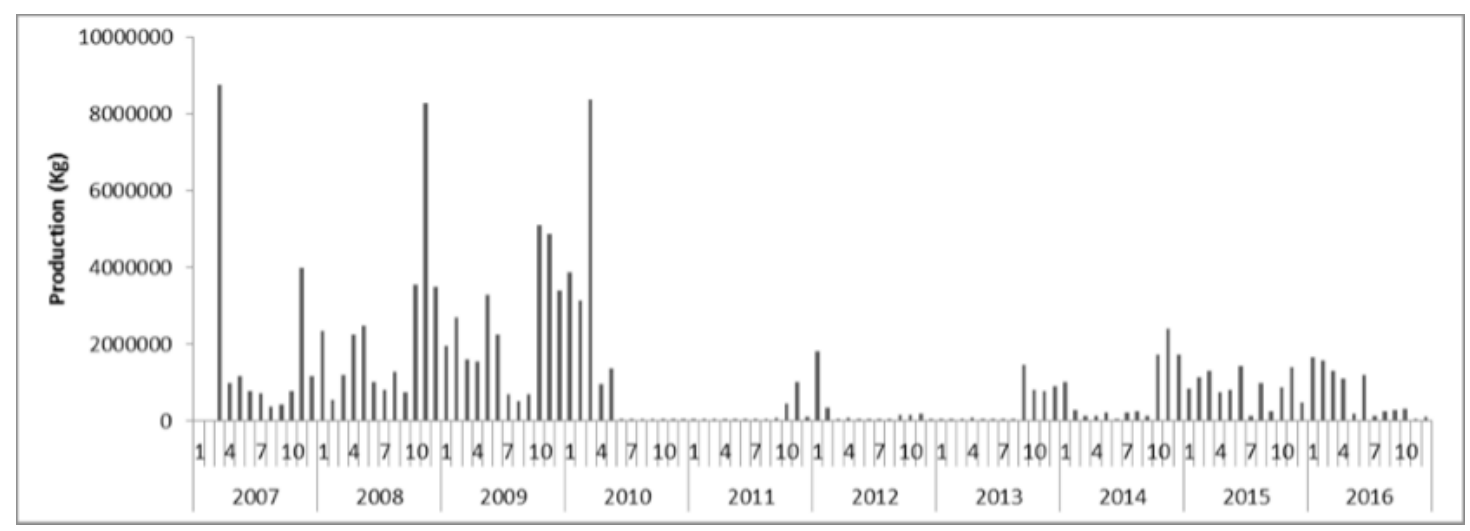

Figure 3. Production of sardine (Sardinella lemuru) landed at Muncar Fishing Port East Java Province.

In 2010, sardine production was significantly decreased and continued to disappear in production until 2011. Strong La Nina coupled with moderate negative IOD occurred in 2010, affecting total production loss, nor sardine neither other species of small pelagic decreased in production due to high SSTA in Bali Strait waters.

In 2015, sardine productions start to decrease

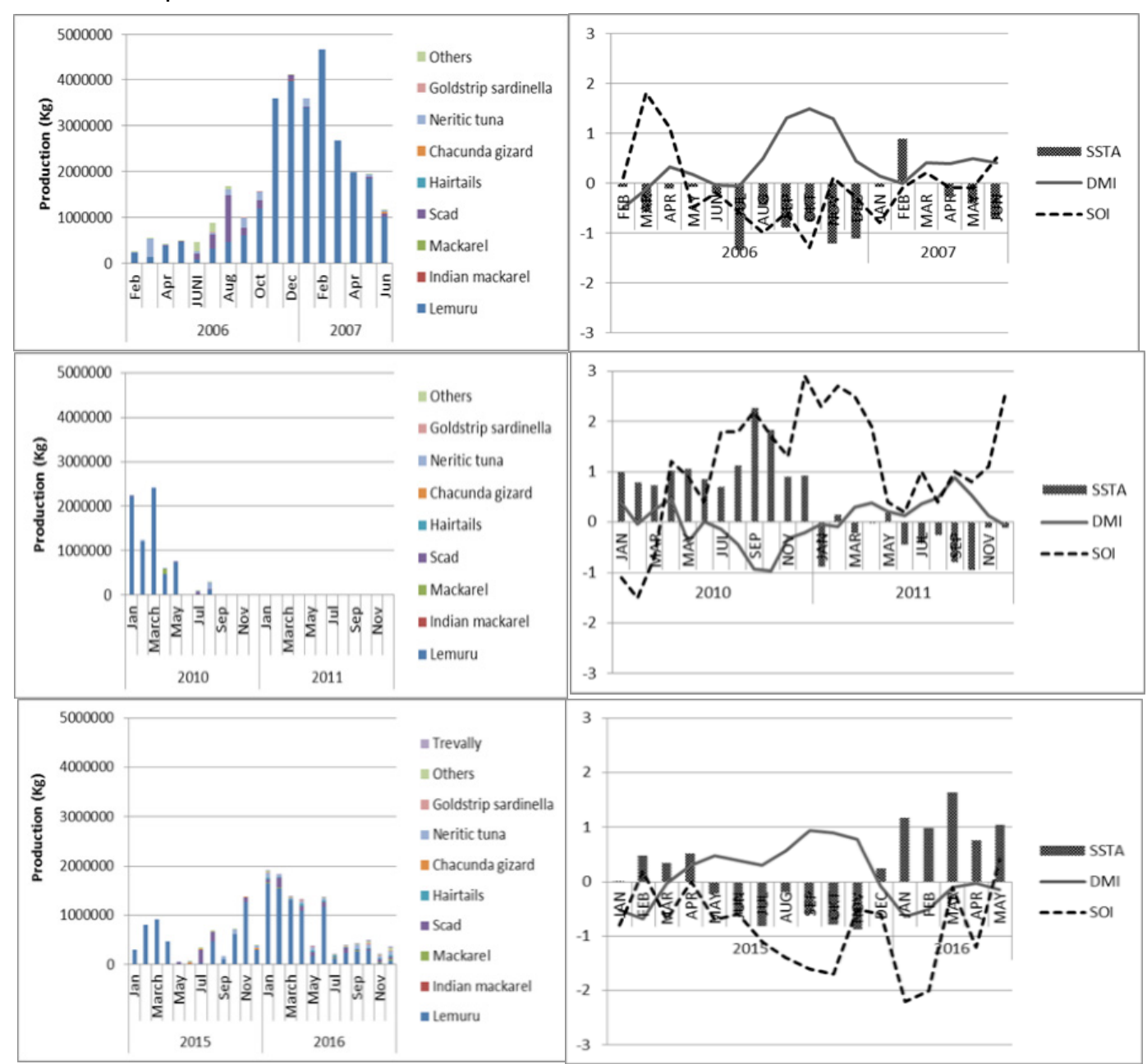

Figure 4. Catch composition of small pelagic fishes landed at Muncar Fishing Port (left)compare to SSTA condition in extreme years (right). significantly in May after medium oscillation in SOI associated with weak DMI. Synergistic effect of moderate positive DMI and strong El Nino affected cooler water temperature and did not show any negative effect to sardine production. Sardine production experienced a significant decreasing since May 2016, two months delayed after super strong El Nino at the beginning of 2016, which was characterized by high increased of SST. 


\section{Oceanography conditions of Bali Strait}

Bali strait lies in between Bali Island and Java Island; it is connected to the Java Sea in the northern part and to Indian Ocean in the southern part. The Indian Ocean gives more influence to the dynamic of Bali Strait. Sea surface temperature of Bali strait was very dynamic, a monthly variation of SST in Bali Strait is influenced by monsoon and also by regional climate phenomena such as Indian Ocean Dipole (IOD) and EI Nino Southern Oscillation (ENSO) (Susilo, 2015).

Time series analysis of the dynamic of SST in Bali Strait shows that there was a signal indicating monsoon effect to SST (Figure 5). Monsoon drives the annual pattern of SST in Bali strait. There was a warm water period that occured in December - March, and cold water period that occured in July - September. West monsoon affects increasing SST, due to the low intensity of wind blow over Bali Strait (Susilo, 2015). In the east monsoon, while the wind blows from Australia into Asia, it will induce upwelling in southern Bali waters (Amri et al., 2013). Thermocline becomes shallower and sea surface temperature cooler (Kunarso et al., 2012). Upwelling brings high nutrient water mass from the deep into a photic layer, and it induces high chlorophyll-a biomass (Kunarso et al., 2011).

Variation in SST leads to the variation in SSTA (sea surface temperature anomaly). The high anomaly occured in 2010 when SST increased more than $1.35 \mathrm{oC}$ for three months respectively. The highest SSTA occured in 2016, when SST increased more than $2.2^{\circ} \mathrm{C}$ for three months respectively. Negative anomaly of SST showed by lower SST compare to average, it was occurred in 2008, 2011 and 2015 (Figure 6).

High anomaly of SST creates an extreme condition in Bali Strait waters. According to Kunarso et al. (2011), ENSO and IOD affect the variation of SST and chlorophyll-a concentration in upwelling region in South Java Sea to South Timor Sea. The scales of SST anomaly are influenced by the combination between IOD and ENSO, in Bali Strait waters SST was higher when La Nina coupled with negative IOD and SST were lower when La Nina coupled with positive IOD. To asses the effect of ENSO phenomenon coupled with IOD on SSTA, we then overlay the SSTA, SOI and DMI and measured their pearson correlation coefficient. Comparison of the temporal pattern of time series SSTA, DMI and SOI, revealed negative correlation (correlation coefficient: -0.73 ) between SSTA and DMI, while ENSO has no correlation with SSTA (Figure 7a). The result indicates that IOD gives more influence to the dynamic of SST in Bali strait compare to ENSO.

ENSO and IOD were also determined the thickness of thermocline. According to Kunarso et al. (2012), the upper threshold of thermocline during El Niño phenomenon was shallower compared to the threshold during La Nina. The thermocline thickness increased in El Nino event compared to La Nina. Thermocline variation defines the vertical migration area of small pelagic fishes. Small pelagic fishes usely migrate above the thermocline, the increasing of thermocline depth would signify the wider vertical migration area of sardine. Analysis of temporal variation of thermocline depth, $\mathrm{DMI}$, and SOI value, revealed a positive correlation between thermocline depth and DMI (correlation coefficient: 0.66), while SOI did not showed any significant correlation (Figure 7).

Chlorophyll-a concentration defines food availability for sardine due to its planktivorous food habit. There is a correlation between sardine production and chlorophyll-a concentration (Lumbangaol et al., 2004; Simbolon et al., 2017). Chlorophyll-a concentration developed as a response of low water temperature as an impact of upwelling process in the southern part of Bali Strait waters. However there are a certain distance and time lag between development of upwelling and increasing of chlorophyll-a concentration, it is influenced by regional climatic anomaly such as IOD (Kunarso et al., 2011; Lumbangaol et al., 2004). The overlay plot of

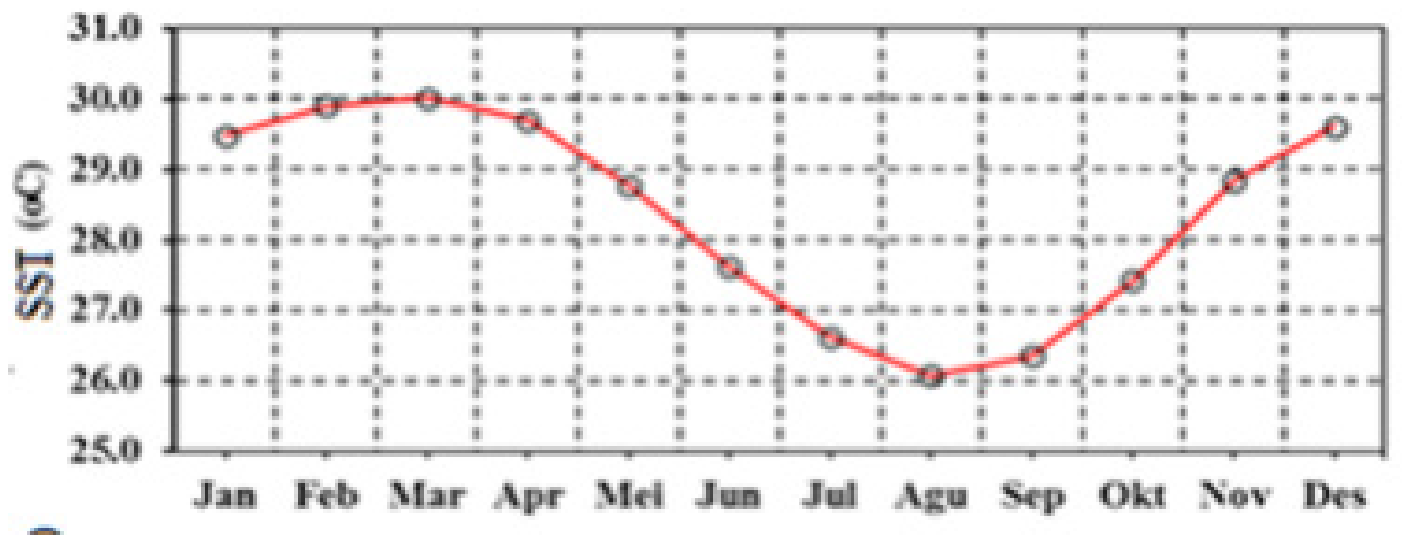

Figure 5. Annual pattern of SST in Bali Strait. 


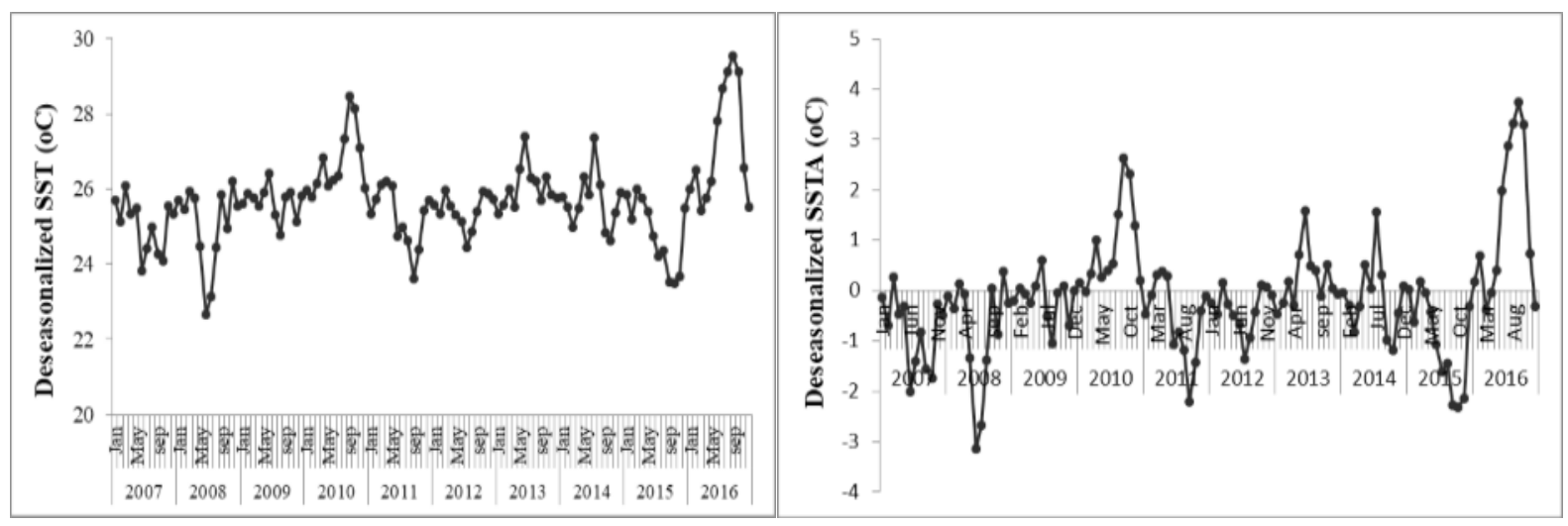

Figure 6. Deseasonalized sea surface temperature and sea surface temperature anomaly.

deseasonalized chlorophyll-a concentration, DMI and $\mathrm{SOI}$ is shown in the Figure (8). Pearson correlation analysis between chlorophyll-a and DMI and SOI did not show any significant correlation between those variabels, indicating that regional climate condition has not directly influenced chlorophyll-a concentration, it might take some processes and time.

\section{The impact of changing environment on Bali sardine production}

The impact of environment changed condition on sardine fishery is revealed by the response of sardine CPUE to the dynamic of environment variable such as SSTA, thermocline depth, chlorophyll-a concentration and salinity. The dynamic of those variabels is influenced by climate anomaly particularly IOD. Besides environment variabels, we also included trip number as a variable in the analysis due to it significant impact on CPUE value of sardine. Trip number is defined as anthropogenic pressure to sardine fishery.

Principal component analysis shows that three principal component axes explained more than 80 $\%$ of the variation among indicators across the sites; therefore three components were significance to describe the case. Chlorophyll-a and thermocline were the most significant variabels, which were very close to factor 1 , they were in opposite quadran indicating that there is a correlation between the increasing of
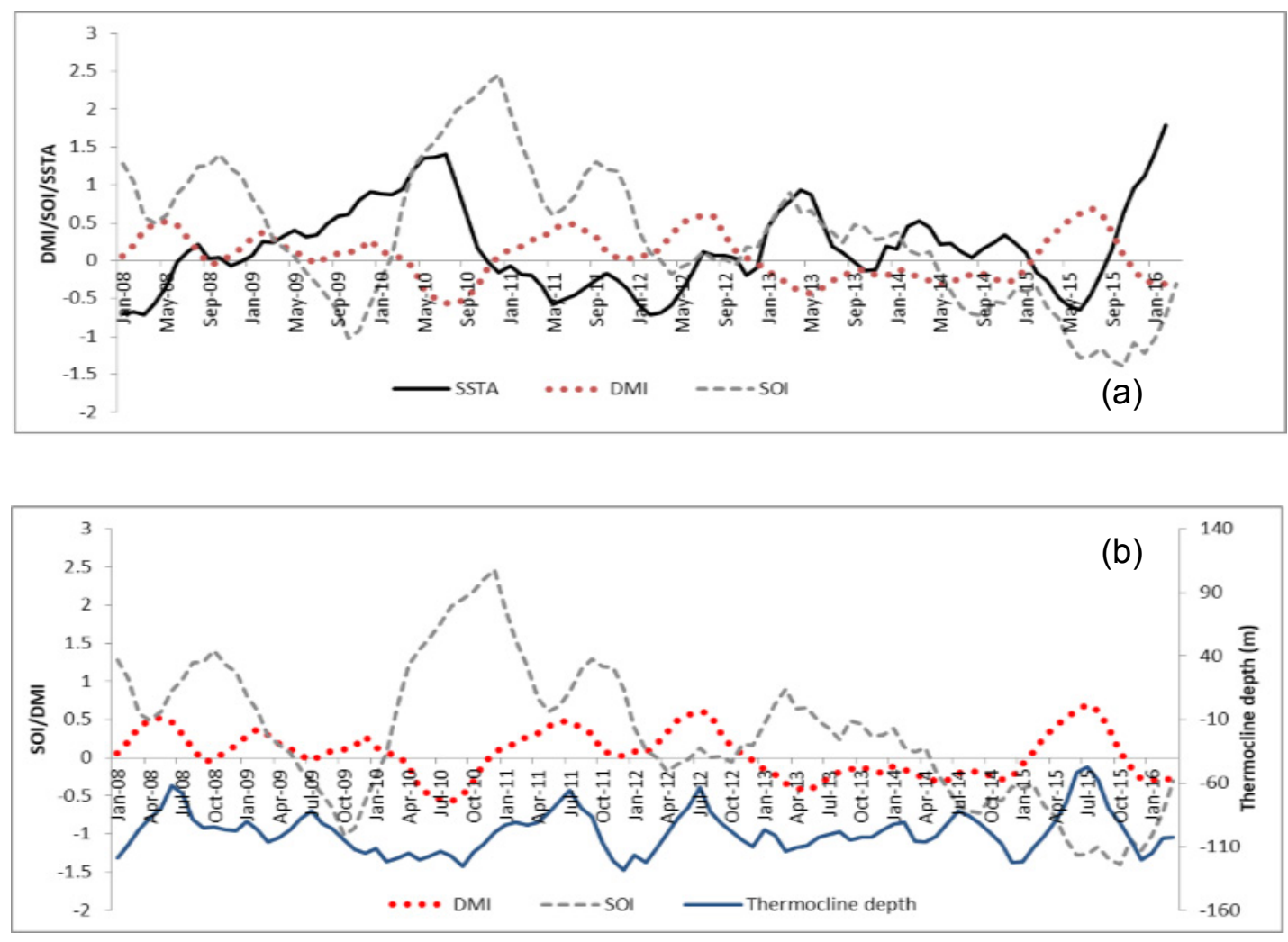

Figure 7. (a) Trendline of SSTA, DMI, and SOI, (b) Trendline of thermocline depth, DMI and SOI. 


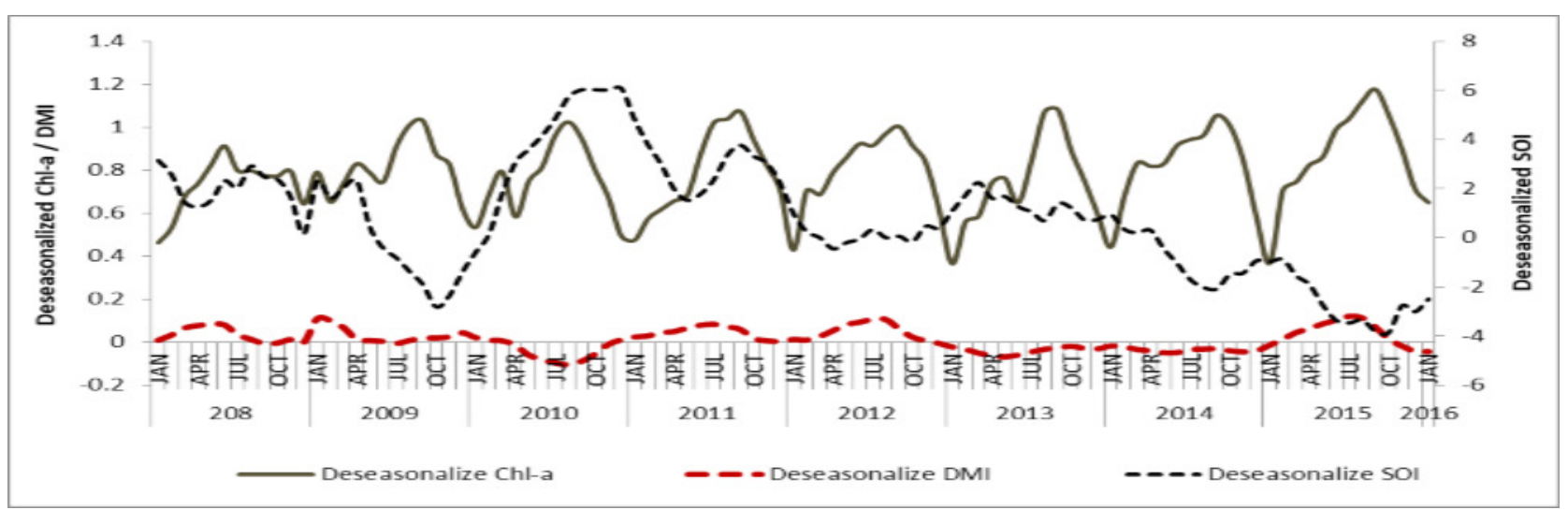

Figure 8. Trendline of deseasonalized chlorophyll-a, DMI and SOI.

thermocline depth and chl-a concentration. Figure 9 (middle) shows that chlorophyll-a concentration had a close associated with salinity and SSTA. Sardine fish abundance represented by CPUE is negatively associated with SSTA and close to factor 2. Figure 9 (left) shows that the increase either in a positive or negative anomaly in SSTA, is associated with fish abundance decreased.

The negative association between sardine CPUE and SSTA could be explained by plotting times series filtered SSTA and CPUE data that showed varian interaction model between those variabels (Figure 10). In 2010, the significant increase of SSTA did not coincide with decreasing CPUE, however significant negative correlation could be seen in the next periods. Insignificant case in 2010 until the beginning of 2013 occured due to inconsistency in database collection since fisheries collapsed and very limited fishing activity. In 2010, there was an extreme climate periods that leads to SST increased significantly to more than $2.26^{\circ} \mathrm{C}$ in September due to post El Nino effect in Bali strait waters. Correlation analysis between SSTA and CPUE in the extreme periods showed that there were a moderate significant negative correlation between them (Table 1).

Effect of extreme climate in 2009 - 2010 brought a significant constant decreasing in CPUE. Sardine fisheries in Bali Strait had been collapsed for more than 2 years. Kim et al. (2011) stated that El Nino event in 2009-2010 was the unique phenomenon, which the strongest warming signal in Central Pacific decays rapidly into strong La Nina. In 2010 SST was higher than normal all over the years and the highest anomaly occurred in September when SSTA reached $2.26^{\circ} \mathrm{C}$. The SST suddenly decreased to $-0.88^{\circ} \mathrm{C}$ lower than a normal condition in January 2011. Sudden changed in temperature was one of the stress factors affecting the metabolism process in fish physiology. Wujdi et al. (2013) found that in the period of August $2010-$ December 2011, more than $90 \%$ of female and male of sardine fish in Bali Strait was immature, and they did not found a mature period of sardine fish at that time. Non-recovery fisheries occurred in Chile and Peru after 1976 which was coincident with the drop of SOI and the presence of long-term warm period reflected in SST (Yanez et al., 2002).
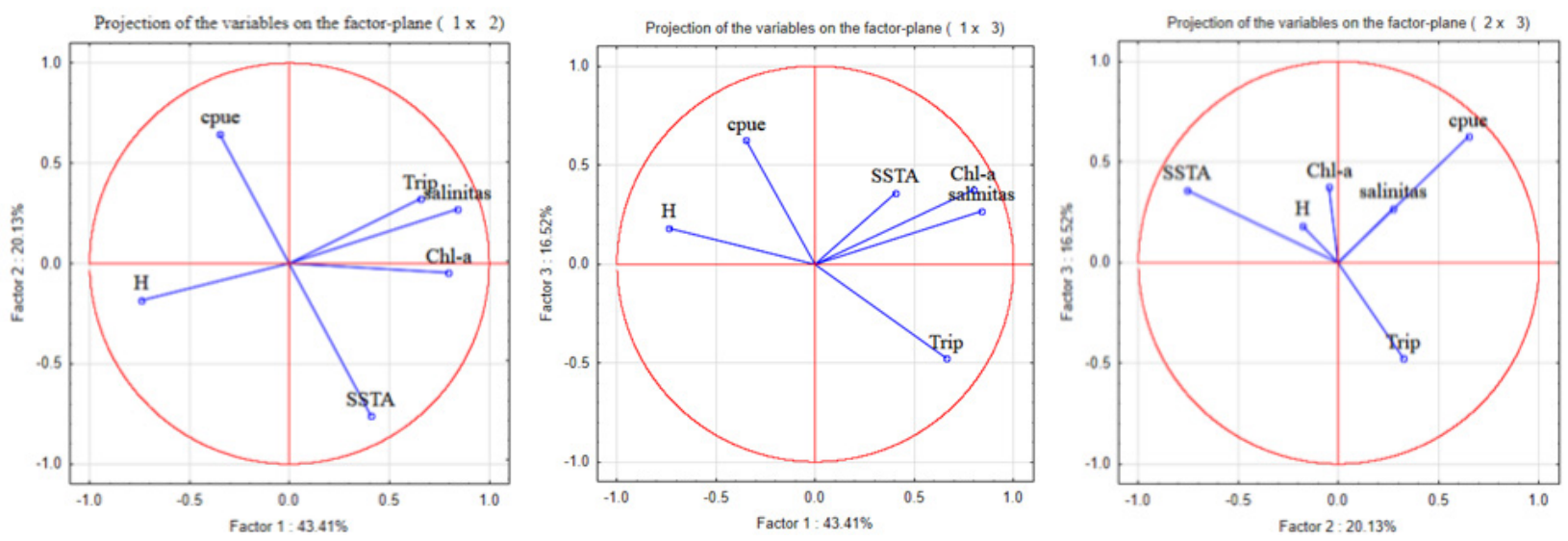

Figure 9. Principle component analysis result showed correlation among variables (left: plot of factor $1 \times 2$; midle: plot of factor $1 \times 3$; plot of factor $2 \times 3$ ). 


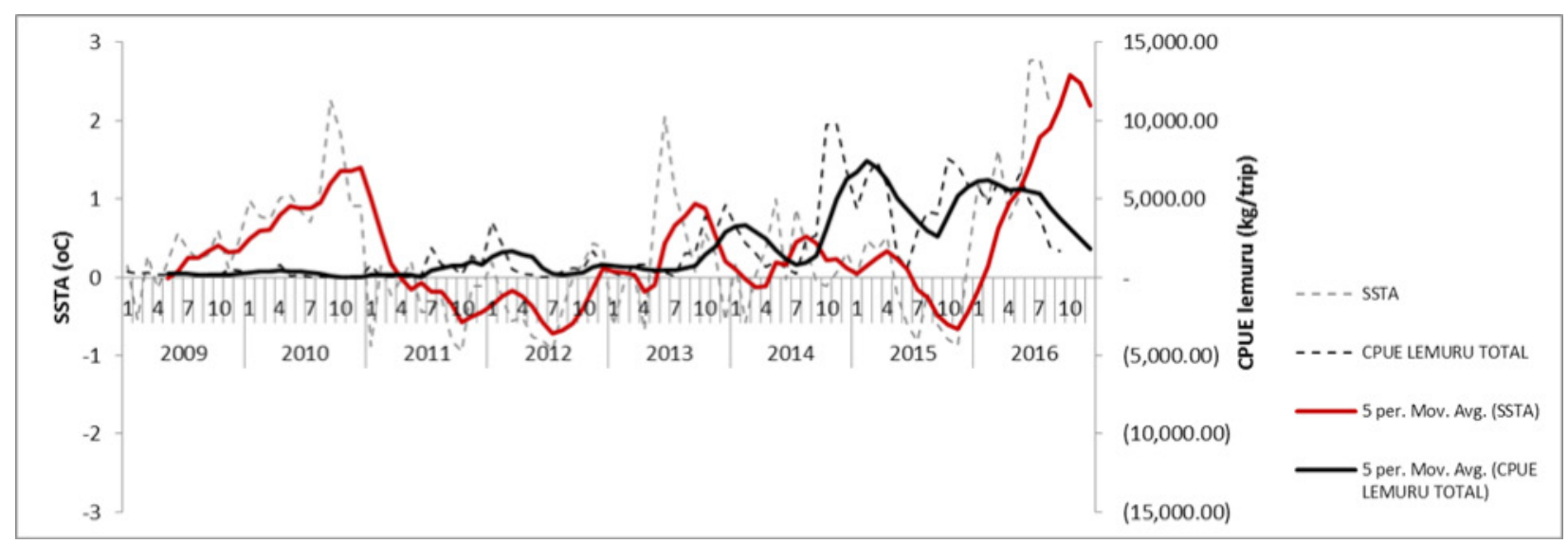

Figure 10. The fluctuation of SSTA and CPUE of sardine (Sardinella lemuru) in Bali Strait.

Tabel 1.

Correlation between SSTA and CPUE of sardine (Sardinella lemuru) at the extreme periods.

\begin{tabular}{lll}
\hline Climate phenomenon & Periods & Correlation with CPUE \\
\hline Post El Nino coupled with normal IOD & December 2009 - March 2010 & -0.65 \\
Post La Nina coupled with normal IOD & September 2010 - June 2011 & -0.72 \\
Post El Nino coupled with normal IOD & September 2015 - March 2016 & -0.76 \\
\hline
\end{tabular}

Finding of this research unanimous of Suniada \& Susilo (2017) showed that SST and chl-a was the most significant variabels affecting sardine CPUE. Sardine abundance should be highly determined by chlorophyll-a as their food source (Gaughan \& Mitchell, 1999). Figure 8 showed that chl-a concentration is negatively associated with thermocline depth. Chlorophyll-a concentration is highly influenced by upwelling process that periodically occurs in Bali Strait. Upwelling brings cooler, high salinity and high nutrient water mass from the bottom into the upper layer. This condition explains that chlorophyll-a, salinity and SSTA are in the same quadran in PCA analysis. However, Sartimbul et al. (2010) showed that there is an integrated delay response between SST, Chl-a and CPUE of sardine in Bali Strait.

Sardine is a pelagic species, lived above the thermocline. The thermocline depth dynamic determined their vertical distributions in the water column. Thermocline depth in Bali strait was highly influenced by regional climate phenomena such as ENSO and IOD. While EI Nino periods, thermocline depth in Bali Strait was being shallower and thicker (Kunarso et al., 2012), it minimized the vertical range distributions of sardine. Sardine would distribute shallower and easy to catch by purse seine net, this mechanism influencing the fishing season of sardine (Prasetyo \& Natsir, 2010). Figure 11 showed the dynamic of thermocline depth and the intensity of fishing effort (trip). Significant moderate negative correlation is occurred between thermocline depth and trip. Table 2 showed the correlation coefficient between these two variables in post-El Nino period
(October 2009 - February 2010), post-La Nina period (July 2010 - April 2011) and post El Nino period (July 2015 - February 2016).

As post-El Nino effect occurs in Bali Strait, it turns the water temperature become cooler and the thermocline depth is decreased, the effort to catch sardine is significantly increased. The post La Nina, showed an opposites condition, as it occurs since July 2010 - April 2011 while there were minimum effort to catch sardine due to very low number of catch rate. Increasing water temperature caused by post-La Nina effect is coincided with increased in thermocline depth from $97 \mathrm{~m}$ to $121 \mathrm{~m}$. The vertical distribution area of sardine became wider, and they seem to swim deeper due to SST increased than normal. Prasetyo \& Natsir (2010) showed that density of pelagic fishes tends to be lower and the swimming layer tends to be deeper, cause by la Nina. When the schooling fish is in the deeper water it would decrease catch ability, resulting in a low number of production.

The analysis showed that there is an inter correlation among environment variabels in Bali Strait waters as a habitat of Bali sardine. Dynamic of some environment variables (SST/SSTA, chl-a, salinity, thermocline depth and the number of trip) is simultaneously affecting sardine CPUE. This analysis gives more information on the effect of various oceanographic variables to the seasonal variation of sardine CPUE (Suniada \& Susilo, 2017). Regional climate phenomenon like IOD and ENSO generated the dynamic of water temperature and upwelling intensity resulted in the changing environment of sardine 


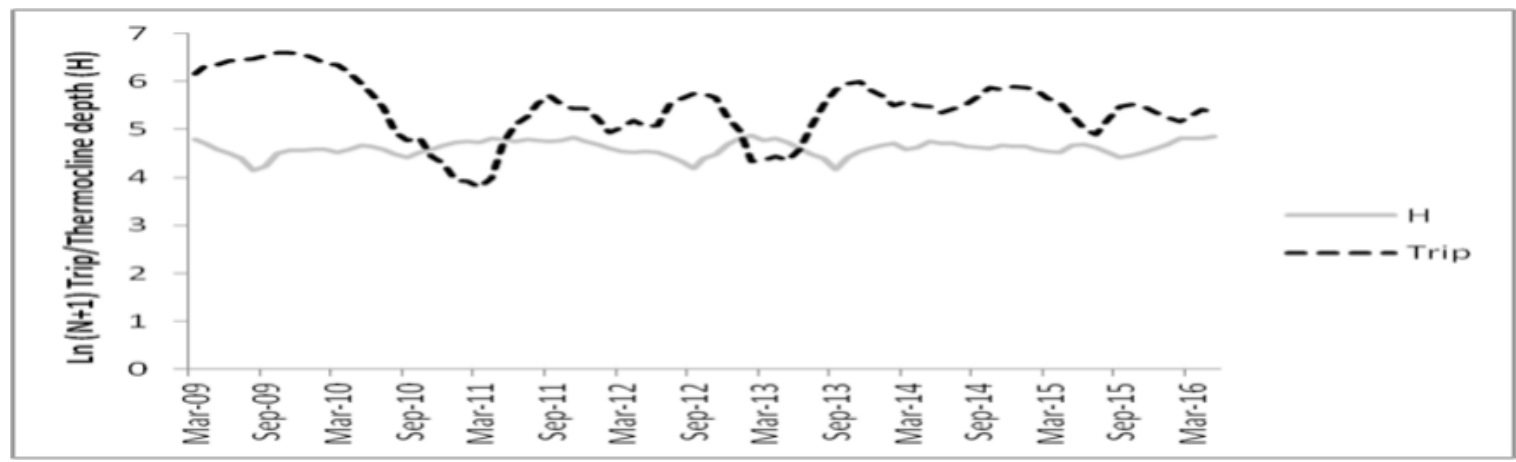

Figure 11. The dynamic of thermocline depth and fishing trip of mini purse seine boat from Pengambengan Fishing Port Base.

Table 2.

Correlation between thermocline depth $(\mathrm{H})$ and trip of mini purse seine boat

\begin{tabular}{lll}
\hline Climate phenomenon & Periods & Correlation coefficient \\
\hline Post El Nino & October (2009) - February (2010) & -0.69 \\
Post La Nina & July (2010) - April (2011) & -0.77 \\
Post-El Nino & July (2015) - February (2016) & -0.61 \\
\hline
\end{tabular}

habitat. When ENSO and IOD combination turns out the increasing of water temperature, it leads to a loss production of sardine, otherwise decreasing water temperature due to ENSO and IOD combination that generated upwelling process it leads to a production increase of sardine.

\section{CONCLUSION}

The CPUE of sardine was determined by the interaction of environment variabels (SST/SSTA, salinity, thermocline depth), food source availabity (Chl-a) and anthropogenic pressure (fishing trip) simultaneously, however SSTA gives a significant negative correlation on CPUE. Regional climate phenomenon causing extreme condition in Bali Strait waters leads to unstable environment for sardine habitat. Drastically changing habitat condition by influenced of extreme condition leads to disruption of sardine CPUE.

\section{ACKOWLEDGEMENTS}

This paper is a contribution of the research activities "Assessment of the impact of Climate variability and its Potential Impact of Climate Change to Small Pelagic Fishes and Fisheries Makassar Strait and Bali Strait". The authors would like to thanks Centre for Fisheries Research for funding and all stakeholders of sardine fisheries in Bali Strait for their contribution in providing information regarding the sardine fisheries.

\section{REFFERENCE}

Amri K., Manurung, D., Gaol, J.L. \& Baskoro, M.S. (2013). The Characteristics of Sea Surface
Temperature and Upwelling process in Indian ocean Dipole Positive Phase in Western Sumatera and Southern West Java Waters. Jurnal Segara. 9(1): 23-35.

Gaughan D.J \& Mitchell, R.W.D. (1999). The Biology and Stock Assessment of the Tropical Sardine, Sardinella lemuru, off the Mid-west Coast of Western Australia. Final Report. FRDC Project 95/037 June 1999 ISBN 073098431 1. Fisheries Research \& Development Corporation. Fisheries Western Australia.

http://www.jamstec.go.jp. SST DMI dataset (monthly from 19870 to present) derived from HadISST dataset. Accessed on October 6th 2016.

https://www.ncdc.noaa.gov. Southern Oscillation Index

Kim, W.M., Yeh, S.W., Kim, J.H., Kug, J.S. \& Kwon, M.H. (2011). The unique 2009 - 2010 El Nino event: a fast phase transition of warm pool El Nino to La Nina. Geophysical Research Letters, Vol. 38, L1 5809, doi:10.1029/2011GL048521.

Kunarso., Hadi, S., Ningsih, N.S. \& Baskoro, M.S. (2011). Variability in temperature and Chlorophyll-a in Upwelling Area in the ENSO and IOD Conditions in Southern Java to Timor Waters. Jurnal IImu Kelautan. 16(3): 171-180. ISSN 0853-7291.

Kunarso., Ningsih, N.S. \& Baskoro, M.S. (2012). Changes in the Depth and Thickness of Thermocline in ENSO, IOD and Monsoon Conditions in Southern Java to Timor Waters. 
Jurnal IImu Kelautan. 17(2): 87 - 98.

Lumbangaol, J., Wudianto., Pasaribu, B.P., Manurung, D. \& Endriani. (2004). The fluctuation of chlorophyll-a concentration derived from satellite imagery and catch of oily sardine (Sardinella lemuru) in Bali Strait. Remote Sensing and Earth Science 1(1): $24-50$.

Mahrus, S.B Sumitro, N. Widodo \&A. Sartimbul. (2012). The Association between Genetic Variations and Omega 3 Production on Sardinella lemuru in Lombok Strait. IOSR Journal of Agriculture and Veterinary Science (IOSR-JAVS) (1)6: 12 - 16. ISSN: 2319-2380, ISBN: 2319-2372.

Merta, I.G.S. (1992). Population dynamic of Bali sardine, Sardinella lemuru Bleeker 1983 (Pisces: Clupeidae) in Bali Strait and its alternative management. Doctoral Disertation. Bogor Agricultural University, Bogor.

Prasetyo, A.P. \& Natsir, M. (2010). The Impact of extreme Climate to Lemuru Fisheries in Bali Strait. Proceeding. Seminar on The best Research Result 2010 The Agency of Marine and Fisheries Research and Development: 21-38 pp. ISBN : 978-979-3692-33-3.

Purwanto. (2011). Bio-Economic Optimal Levels of The Bali Strait Sardine Fishery Operating in a Fluctuating Environment. Indonesia Fisheries Research Journal. 17(1): 1-12.

Sartimbul, A., Nakata, H., Rohadi, E., Yusufa, B. \& Kadarisman, H.P. (2010). Variations in chlorophyll-a concentration and the impact on Sardinella lemuru catches in Bali Strait, Indonesia. Progress in Oceanography. 87: 168-174.

Simbolon, D., Nurfaqih, L. \& Sala, R. (2017). Analysis of oil sardine (Sardinella lemuru) fishing grounds in the Bali Strait waters, Indonesia. 2010. AACL. Bioflux 10(4): 830 - 843. http://bioflux.com.ro/ aacl.

Suniada., K.I. \& Susilo, E. (2017). Keterkaitan kondisi oseanografi dengan perikanan pelagis di perairan Selat Bali. J.Lit.Perikan.Ind. Vol.23(4): 275-286.

Susilo, E. (2015). Variability of Environment Factors in Lemuru Habitat in Bali Strait Waters Using Oceanographic Data and In Situ Measurement. Omni-Akuatika. (XIV)20: 13-22.

Wujdi, A., Suwarso. \& Wudianto. (2013). Biology Reproduction And Spawning Season of Bali Sardinella (Sardinella lemuru Bleeker 1853) In
Bali Strait Waters. BAWAL, Vol. 5(1): 49-57.

Wujdi, A. \& Wudianto. (2015). The status stock of Bali sardine (Sardinella lemuru Bleeker, 1853) in The Bali Strait Waters. Jurnal Penelitian Perikanan Indonesia. 21(4): 253 - 260.

Yanez, E., Barbieri, M.A., Silva, C., Castillo, J., Nieto, K., Bohm, G., Gomez, F. \& Cordova, J. (2002). Climate variability and Pelagic Fisheries in the South-Eastern Pacific. Investigaciones marinas. 3(1). On-line version. ISSN 0717-7178. http:// dx.doi.org/10.4067/S0717-71782002030100070. 